\title{
Theoretical Performance Comparison of Stepped Solar Still Using Different Nanofluids
}

\author{
Y. A. F. El-Samadony, S. A. El-Agouz and A.E. Kabeel \\ Mechanical Power Engineering Department, Faculty of Engineering, Tanta University, Egypt \\ samadony25@yahoo.co.uk, elagouz2011@yahoo.com, kabeel6@hotmail.com
}

\begin{abstract}
In the present work, theoretical performance comparison of stepped solar still using different nanofluids is performed. Four nano fluids are used in this study. The used nano- particles are aluminium oxide, Copper oxide, Titanmum dioxide, and Silicon oxide. The effect of nano-particles volume fraction on the still daily productivity and efficiency are studied. The estimated cost to produce one distalled liter for conventional and stepped solar stills with and without nano-particles is obtained. It is found that using a nano-fluid may slightly increase the still productivity. Finally a good agreement between the present theoretical work and previous experimental results has been obtained.
\end{abstract}

Keywords: stepped solar still, distillation; nano-fluid;nano-particle, theoretical

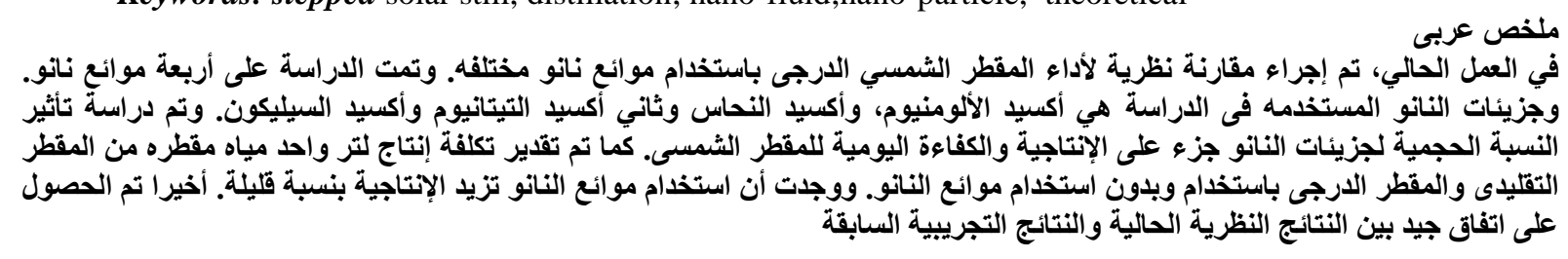

\section{INTRODUCTION}

Water is essential to life. As the available fresh water is fixed on the earth and its demand is increasing day by day due to increasing population and rapidly increasing of industry, hence there is an essential and an earnest need to get fresh water from the saline/brackish water present on or inside the earth. This process of getting fresh water from saline/ brackish water can be done easily and economically by desalination [1]. The solar stills are simple and have no moving parts and it can be used anywhere with lesser number of problems. The operation of a solar still is very simple and no special skill is required for its operation and maintenance [2]. The distilled water production rate can be increased by varying design of the solar still, depths of water, salt concentration, location and different absorbing materials, evaporative techniques and use of nanofluids [3]. A solar still output might be affected by many factors, including brine depth, vapor leakage, thermal insulation, cover slope, material shape, and climate $[4,5]$. The latent heat is normally wasted on the cover, therefore the system efficiency is relatively low with a daily production of about 3-4 $1 / \mathrm{m}^{2}$ [6]. Solar stills have been extensively studied [7]. Later, researchers developed different kinds of solar still systems, such as: solar stills coupled with solar collectors, solar stills with condensers, solar stills under low pressure [8], solar stills with heat recycling [9], multi-stage/multi-effect solar stills, solar stills with heat storage [10], and hybrid solar still/PV systems [11]. Two modifications of solar water distillers using cement and aluminum absorbers were presented experimentally [12]. The first modification used separated condenser to purge vapor from the cement absorber distiller, while second modification used a plate thermosyphon. The daily productivity of the cement and aluminum absorber distiller was 2.08 and $2.96 \mathrm{l} /\left(\mathrm{m}^{2}\right.$ day).

Other studies have considered the use of phase change material (PCM) as storage media in stepped solar stills. The transient performance of a stepped solar still with built-in latent heat thermal energy storage was studied [13]. The results showed that the basin still integrated with heat storage system is efficient for water provision during the lack of sunlight, especially at night. In addition, a new mathematical model developed under the simplifying assumptions to study the thermal performance of a single basin solar still with phase change material (PCM) [14]. A weir-type cascade stepped solar still constructed with built-in latent heat as a thermal energy storage system to improve the still productivity was investigated [15]. The results showed that the still with PCM was superior in productivity ( $31 \%$ improvement) compared with still without PCM by considering a limited set of data in a typical day.

An innovative idea was to suspend ultrafine solid particles in the fluid for improving the thermal conductivity of the fluid. The fluids with solid-sized nanoparticles suspended in them were called nanofluids. The suspended metallic or nonmetallic nanoparticles change the transport properties, heat 


\section{Y.A.F. El-Samadony, S.A. El-Agouz and A.E. Kabeel}

transfer characteristics and evaporative rate of the base fluid. The carbon nanotube (CNT) -based nanofluids are expected to exhibit superior heat transfer properties compared with conventional water in the solar still and other type of nanofluids and hence the increase in the productivity and efficiency of the solar still [16]. A single basin vacuum solar still made up of copper sheet was fabricated and tested for both the conditions with and without nanofluids [17]. The modified innovative solar still gave a total water consumption of about $7.5 \mathrm{l} / \mathrm{day} / \mathrm{m}^{2}$. Analyze and compare the enhanced performance of a single basin solar still using nanofluids with the conventional water was presented [18]. The addition of nanofluids in the basin surface increases the thermal conductivity by $40 \%$, which in turn increases water temperature by increasing heat transfer rate and thereby increasing the evaporation rate and consequently the efficiency by $60 \%$. The design modification of a single basin solar still was investigated to improve productivity by using nanofluids and also by integrating the stilling basin with external condenser. [19]. The results show that integrating the solar still with external condenser increases the distillated water yield by about $53.2 \%$. The using nanofluids improves the solar still water productivity by about $116 \%$, when the still is integrated with an external condenser.

To the authors' knowledge, theoretical study of the performance of single basin stepped solar still using nanofluids is not studied. The global effect of using both external condenser and $\mathrm{AL}_{2} \mathrm{O}_{3}$ nanoparticle at fixed $0.20 \%$ volume fraction on the productivity of a conventional solar still was studied experimentally [20]. In the present study, performance evaluation of a single basin stepped solar still using different types of nano-particles at different volume fraction is obtained theoretically. Several objectives are formulated to address the overall goal of the present study; these objectives are:

1. Design a theoretical model for conventional and stepped solar still working with and without nano-particles.

2. Study the effect of using different nano-particles at different volume fractions of the stepped solar still productivity.

\section{MATHEMATICAL MODEL}

The energy balance of the stepped solar still may be applied for three regions: basin (absorber plate), saline water, and glass cover. The basin plate temperature, saline water temperature, and glass cover temperature can be evaluated at every instant. The following assumptions are considered for the solar still energy equations:

- Steady-state conditions throughout the stepped solar still.
- The glass cover is assumed to be thin, therefore no incident radiation will be absorbed by the glass.

- The solar still is vapor leakage proof. Energy balance for the basin plate [21],

$m_{b} C p_{b} \frac{d t_{b}}{d \tau}=\left(\alpha_{b}\right) A_{b} I-Q_{b n f}-Q_{\text {loss }}$

The convective heat transfer rate between basin and water [22, 23]

$Q_{b n f}=h_{b n f} A_{b}\left(t_{b}-t_{n f}\right)$

The convective heat transfer coefficient between basin and water, $\mathrm{h}_{\mathrm{bnf}}$ is given by [22]:

$h_{b n f}=0.54 \frac{K_{n f}}{X^{\prime}}[G r \operatorname{Pr}]^{0.25}$
$G r=\left[\frac{\rho_{n f}^{2} g \beta_{n f}\left(T_{p}-T_{n f}\right)\left[X^{\prime}\right]^{3}}{\mu_{n f}^{2}}\right]$
$P r=\left[\frac{C_{p} \mu}{K}\right]_{n f}$

Thermal conductivity, thermal coefficient and dynamic viscosity of nanofluids is given by [24,25] and the thermophysical properties of nanoparticales are shown in Table (1) [26]:

$K_{n f}=K_{b f} \frac{\left(K_{n p}+2 K_{b f}\right)-2 \varphi\left(K_{b f}-K_{n p}\right)}{\left(K_{n p}+2 K_{b f}\right)+\varphi\left(K_{b f}-K_{n p}\right)}$
$\beta_{n f}=(1-\varphi) \beta_{b f}+\varphi \beta_{n p}$
$\boldsymbol{\mu}_{\mathrm{nf}}=\boldsymbol{\mu}_{\mathrm{bf}}(\mathbf{1}+\varphi)^{\mathbf{1 1 . 3}}\left(\mathbf{1}+\frac{\mathrm{t}_{\mathrm{nf}}}{\mathbf{7 0}}\right)^{-\mathbf{0 . 0 3 8}}\left(1+\frac{\mathbf{d}_{\mathrm{np}}}{\mathbf{1 7 0}}\right)^{-\mathbf{0 . 0 6 1}}$

The heat losses by convection through the basin base and sides to the ground and surrounding, is given as [27].

$Q_{\text {loss }}=U_{b} A_{b}\left(t_{b}-t_{a}\right)$

Where $\mathrm{U}_{\mathrm{b}}$ is taken [28] as, $14 \mathrm{~W} / \mathrm{m}^{2} \mathrm{~K}$

The energy balance of the saline water [21],

$m_{n f} C p_{n f} \frac{d t_{n f}}{d \tau}=\left(\alpha_{n f}\right) A_{n f} I+Q_{b n f}-Q_{r n f}-$

$Q_{c n f}-Q_{e}-Q_{m w}$

Heat capacity and density of nanofluids is given by [24]:

$C p_{n f}=\frac{(1-\varphi) C p_{w} \rho_{w}+\varphi C p_{n p} \rho_{n p}}{\rho_{n f}}$
$\rho_{n f}=(1-\varphi) \rho_{w}+\varphi \rho_{n p}$

The radiation heat transfer from the basin to glass cover is given by [28]

$$
\begin{aligned}
& Q_{r n f}=\left[\frac{1}{\varepsilon_{n f}}+\frac{1}{\varepsilon_{g}}-1\right]^{-1} A_{n f} \sigma\left[\left(t_{n f}+273\right)^{4}-\right. \\
& \left.\left(t_{g}+273\right)^{4}\right]
\end{aligned}
$$

Due to solar still geometry, the thickness of insulation in the conventional solar still is smaller than that of the stepped solar still. Therefore, stepped solar still has smaller overall heat transfer coefficient than that conventional solar still.

The convective heat transfer rate between saline water and the glass cover is given by $[22,23]$, $Q_{c n f}=h_{c n f} A_{n f}\left(t_{n f}-t_{g}\right)$

The convective heat transfer coefficient between saline water and glass cover, $h_{c n f}$, is given by [29] 


\section{Y.A.F. El-Samadony, S.A. El-Agouz and A.E. Kabeel}

$\mathrm{h}_{\mathrm{cnf}}=0.884\left[\mathrm{t}_{\mathrm{nf}}-\mathrm{t}_{\mathrm{g}}+\frac{\left(\mathrm{p}_{\mathrm{nf}}-\mathrm{p}_{\mathrm{g}}\right)\left(\mathrm{t}_{\mathrm{nf}}+273\right)}{268900-\mathrm{p}_{\mathrm{nf}}}\right]^{1 / 3}$

Where

$\mathbf{p}_{\text {nf }}=\mathbf{e}^{\left(25.317-\frac{5144}{\mathrm{t}_{\mathrm{nf}}+273}\right)}$ and $\mathbf{p}_{\mathbf{g}}=\mathbf{e}^{\left(25.317-\frac{5144}{\mathrm{tg}_{\mathrm{g}}+273}\right)}(16)$

The evaporative heat transfer between saline water and the glass is given by $[22,23]$

$Q_{e}=\left(16.237 \times 10^{-3}\right) h_{c n f} A_{n f}\left(p_{n f}-p_{g}\right)$

The energy needed to heat the makeup water, $Q_{m w}$, is given as follows:

$Q_{m w}=m_{r e}\left(c_{p w} t_{w}-c_{p a} t_{a}\right)$

The energy balance of the glass cover [21],

$\mathrm{m}_{\mathrm{g}} \mathrm{Cp}_{\mathrm{g}} \frac{\mathrm{dt}_{\mathrm{g}}}{\mathrm{d} \tau}=\left(\alpha_{\mathrm{g}}\right) \mathrm{A}_{\mathrm{g}} \mathrm{I}+\mathrm{Q}_{\mathrm{rnf}}+\mathrm{Q}_{\mathrm{cnf}}+$

$Q_{e}-Q_{c g}-Q_{r g}(19)$

For conventional or stepped solar still, the convective heat transfer between the glass and the sky is given by [29]:

$Q_{c g}=h_{c a} A_{g}\left(t_{g}-t_{s k y}\right)$

The sky temperature is given by [30]

$t_{s k y}=t_{a}-6.0$

$h_{c a}=5.7+3.8 V_{a}$

For conventional or stepped solar still, the radiative heat transfer between the glass and the sky is given by $[22,23]$,

$Q_{r g}=\varepsilon_{g} A_{g} \sigma\left[\left(t_{g}+273\right)^{4}-\left(t_{s k y}+273\right)^{4}\right](23)$

Solar still productivity

$m_{r e}=\frac{Q_{e}}{h_{f g}}$

At the first iteration, saline water temperature, glass temperature and basin plate temperature are taken as ambient temperature and the increase in basin temperature $\left(\mathrm{dt}_{\mathrm{b}}\right)$, saline water temperature $\left(\mathrm{dt}_{\mathrm{nf}}\right)$, and glass temperature $\left(\mathrm{dt}_{\mathrm{g}}\right)$ is computed by solving Eqs. (1, 10 and 20) for stepped still with nanofluids. The equations are evaluated numerically using the first order backward difference formula [30]. The size of the time step is one second. In the next time step, the parameters are redefined as follows:

$t_{n f}=t_{n f}+d t_{n f}$

$t_{g}=t_{g}+d t_{g}$

$t_{b}=t_{b}+d t_{b}$

The daily efficiency of the still, $\eta_{d}$, is obtained by the summation of the hourly condensate production $m_{e w}$, multiplied by the latent heat $h_{f g}$, hence the result is divided by the daily average solar radiation $I(t)$ over the whole area $A$ of the device:

$\eta_{d}=\frac{\sum \dot{m}_{r e} \times h_{f g}}{\sum A \times I(t)}$

To be very close to real ambient conditions, insolation (I) and ambient temperature $\left(\mathrm{t}_{\mathrm{a}}\right)$ are measured at different days from 9 am to $6 \mathrm{pm}$ during the period of July to August 2013 at the Faculty of Engineering, Tanta University, Egypt, and the average values of insolation and ambient temperature are used. The physical and operating parameters that used in the theoretical calculations are shown in Table (2). The physical parameters used are taken as that of [31].

\section{RESULTS AND DISCUSSIONS}

A detailed study of the effect of mixing of Aluminium oxide $\left(\mathrm{Al}_{2} \mathrm{O}_{3}\right)$, Copper oxide $(\mathrm{CuO})$, Titanium dioxide $\left(\mathrm{TiO}_{2}\right)$, or Silicon dioxide $\left(\mathrm{SiO}_{2}\right)$ as a nano-material on the stepped solar still performance are made.

Figure (2) illustrates the variation of nano-particle volume fraction with the stepped solar still daily productivity for different nano-fluids. It could be seen from this figure that as a nano-particle volume fraction increases the stepped solar still daily productivity slightly increases. In fact, mixing nanoparticles with saline water inside the solar still change the thermophysical properties of the base fluid such as specific heat, thermal conductivity, thermal diffusivity, and viscosity, which may enhance the convective heat transfer coefficients and consequently heat transfer and evaporation rate. As the base fluid in the solar still is quiescent, then the value of the nano-fluid's specific heat has the major effect on evaporation processes. Normally, as the added amount of nano-particles increases, nano-fluid specific heat decreases. Therefore, for the same solar intensity, the temperature of the saline water, which mixed with nano-particles is higher than that without, as shown in Fig. 3. The results show that as the volume fraction of $\mathrm{Al}_{2} \mathrm{O}_{3}, \mathrm{CuO}, \mathrm{TiO}_{2}$, and $\mathrm{SiO}_{2}$ is increased from 0 to $4 \%$ the value of nano-fluid specific heat decreased by $11.6 \%, 18.3 \%, 12.6 \%$ and $11.6 \%$ respectively. It can be noted from Fig. 2 also that the lower nano-particle specific heat, the higher still productivity. Finally, it is found that, the effect of adding $\mathrm{Al}_{2} \mathrm{O}_{3}, \mathrm{TiO}_{2}$, and $\mathrm{SiO}_{2}$, nano-particles with volume fraction less than $0.8 \%$ on the still productivity is nearly negligible.

Figure (4) illustrates the variation of nano-particle volume fraction with the stepped solar still daily efficiency for $\mathrm{Al}_{2} \mathrm{O}_{3}, \mathrm{CuO}, \mathrm{TiO}_{2}$, and $\mathrm{SiO}_{2}$ nanofluids. It could be seen from this figure that as a nano-particle volume fraction increases the stepped solar still daily efficiency slightly increases. The results show that as the volume fraction of $\mathrm{Al}_{2} \mathrm{O}_{3}$, $\mathrm{CuO}, \mathrm{TiO}_{2}$, and $\mathrm{SiO}_{2}$ is increased from 0 to $4 \%$ solar still daily efficiency, increased by $0.44 \%, 0.96 \%$, $0.43 \%$ and $0.36 \%$ respectively.

Figure (5) illustrates the hourly variations of still productivity per unit area of the conventional still, stepped still without nano-particle and stepped still with $\mathrm{Al}_{2} \mathrm{O}_{3}, \mathrm{CuO}, \mathrm{TiO}_{2}$, and $\mathrm{SiO}_{2}$ nano-fluid. 
Theoretical Performance Comparison of Stepped Solar Still Using Different Nanofluids

\section{Y.A.F. El-Samadony, S.A. El-Agouz and A.E. Kabeel}

\section{Present work validation}

Figure (6) compares between the present work and Omara et al [31] output results for hourly productivity of stepped solar still and conventional still. The present theoretical work is fed with Omara et al [31] for the same insolation (I) and ambient temperature $\left(\mathrm{t}_{\mathrm{a}}\right)$ working conditions. It could be seen from this figure that the present work results are nearly close to Omara et al [31] results.

\section{PRODUCTIVITY COST EVALUATION}

The total cost of the solar still, C, can be calculated as follows:

$\mathrm{C}=\mathrm{F}+\mathrm{V}$

Where: $F$ The total fixed cost, \$

$\mathrm{V}$ Variable cost which equals $0.3 \mathrm{~F}$ per year, as reported in [32], \$

The fixed cost of the conventional and setpped solar still is about $103 \$$ and $132 \$$ respectively. The price of the added nano-particles is calculated as reported in [33]. The expected solar still lifetime is assumed to be about 10 years. Also, it is assumed that the solar still operates 340 days in the year, which represent sun rise days along the year in Egypt. Table (3) shows the estimated cost of one liter for conventional and stepped still with and without nano-particles. It could be seen from table (3) that the estimated cost of one destailed liter is increased as a nano-particles are used.

\section{CONCLUSIONS}

Based on the present results, the following conclusions can be presented:

1. The productivity of the basin solar still can be slightly increased by mixing nan-particles with saline water inside the still and the highest performance can be occurs for low specific heat nano-particles.

2. The volume fraction of $\mathrm{Al}_{2} \mathrm{O}_{3}, \mathrm{TiO}_{2}$, and $\mathrm{SiO}_{2}$, should be more than $0.8 \%$ to achieve better still productivity.

3. In the present study Cuo achieves better productivity than $\mathrm{Al}_{2} \mathrm{O}_{3}, \mathrm{TiO}_{2}$, or $\mathrm{SiO}_{2}$.

4. More experimental work is recommended for more validation

5. Mixing the present nano-particles with saline water increases the estimated cost of one distilled liter

\section{REFERENCES}

[1] O. O. Badran, M. M. Abu-khader, Evaluating thermal performance of a single slope solar still, Heat and Mass Transfer.43 (2007) 985-995.

[2] M. K. Gnanadason, P. Senthilkumar, G. Sivaraman, Design and performance analysis of a vacuum single basin solar still, International Journal of Advanced Engineering Technology 2(4) (2011) 174-181.
[3] E Natarajan, R. Sathish, Role of nanofluids in solar water heaters, International Journal Advanced Manufacturing Technology 170(8) (2009) 1876-1882.

[4] R. Tripathi, G. N. Tiwari, Effect of water depth on internal heat and mass transfer for active solar distillation, Desalination 173 (2005) 187-200.

[5] H. N. Singh, G. N. Tiwari, Monthly performance of passive and active solar stills for different Indian climatic conditions, Desalination 168 (2004) 145-50.

[6] S. Kalogirou, Survey of solar desalination systems and system selection, Energy 22 (1997) 69-81.

[7] K. Sampathkumar, T. V. Arjunan, P. Pitchandi, P. Senthilkumar, Active solar distillation- a detailed review, Renewable and Sustainable Energy Reviews 14 (2010) 1503-26.

[8] J. H. Tay, S. C. Low, S. Jeyaseelan, Vacuum desalination for water purification using waste heat, Desalination 106 (1996) 131-5.

[9] K. Schwarzer, E. Vieira da Silva, B. Hoffschmidt, T. Schwarzer, A new solar desalination system with heat recovery for decentralised drinking water production, Desalination 248 (2009) 204-11.

[10] A. A. El-Sebaii, A. A. Al-Ghamdi, F. S. Al-Hazmi, A. S. Faidah, Thermal performance of a single basin solar still with PCM as a storage medium, Applied Energy 86 (2009)1187-95.

[11] S. Kumar, A. Tiwari, An experimental study of hybrid photovoltaic thermal (PV/T) active solar still, International Journal of Energy Research 32(2008) 84758.

[12] M. M. Mohamed, M. A. Abd El-Baky, Thermosyphon solar water distiller of cement and aluminum absorber with auxiliary condenser, International Journal of Water Resources and Environmental Engineering 3(13) (2011) 308-323.

[13] A.M. Radhwan, Transient performance of a stepped solar still with built-in latent heat thermal energy storage, Desalination 171 (2004) 61-76.

[14] A.A. El-Sebaii, A.A. Al-Ghamdi, F.S. Al-Hazmi, A.S. Faidah, Thermal performance of a single basin solar still with PCM as a storage medium, Applied Energy 86 (2009) 1187-1195.

[15] M. Dashtban, F.F. Tabrizi, Thermal analysis of a weirtype cascade solar still integrated with PCM storage, Desalination 279 (2011) 415-422.

[16] Y. Hwang, J. K. Lee, C. H. Lee, Y. M. Jung, S. I. Cheong, C. G. Lee, B. C. Ku, S. P. Jang, Stability and thermal conductivity characteristics of nanofluids, Thermochimica Acta, 455(1-2) (2007) 70-74

[17] M. J. Assael, C. F. Chen, N. Metaxa, W. A. Wakeham, Thermal conductivity of suspensions of carbon nanotubes in water, International Journal Thermophysics 25(4) (2004) 971-985

[18] M. K. Gnanadason, P. S. Kumar, G. Jemilda, S. R. Kumar, Effect of nanofluids in vacuum single basin solar still, International Journal of Scientific and Engineering Research, 3(1) (2012). 2229-5518.

[19] M. K. Gnanadason, P. S. Kumar, V. H. Wilson, G. Hariharan, N. S. Vinayagamoorthi, Design and performance analysis of an innovative single basin solar nanostill, Smart Grid and Renewable Energy 4 (2013) 88-98. 


\section{Y.A.F. El-Samadony, S.A. El-Agouz and A.E. Kabeel}

[20] A. E. Kabeel, Z. M. Omara, F. A. Essa, Enhancement of modified solar still integrated with external condenser using nanofluids: An experimental approach, Energy Conversion and Management 78 (2014) 493-498.

[21] V. Velmurugan, S. Pandiarajan, P. Guruparan,H. Subramanian,D. Prabaharan, K. Srithar, Integrated performance of stepped and single basin solar stills with mini solar pond, Desalination 249 (2009) 902-909.

[22] V. Velmurugan, S.S. Kumaran, N. Prabhu, K. Srithar, Productivity enhancement of stepped solar still performance analysis, Therm. Sci. 12 (2008) 153-163.

[23] V. Velmurugan, K.J.N. Kumar, T.N. Haq, K. Srithar, Performance analysis in stepped solar still for effluent desalination, Energy 34 (2009) 1179-1186.

[24] W.N. Mutuku-Njane1 and O. D. Makinde, Combined effect of buoyancy force and navier slip on mhd flow of a nanofluid over a convectively heated vertical porous plate, The ScientificWorld Journal Volume 2013, Article ID 725643, 8 pages.

[25] A. M. Hussein, K.V. Sharma, R.A.Bakar, K. Kadirgama, A review of forced convection heat transfer enhancement and hydrodynamic characteristics of a nanofluid, Renewable and Sustainable Energy Reviews 29 (2014) 734-743.

[26] E. B. Ogut, Natural convection of water-based nanofluids in an inclined enclosure with a heat source, International Journal of Thermal Sciences 48 (2009) 2063-2073

[27] D. Rahul, G.N. Tiwari, Characteristic equation of a passive solar still, Desalination 245 (2009) 246-265.

[28] K.K. Murugavel, S. Sivakumar, J. Riaz Ahamed, Kn.K.S.K. Chockalingam, K. Srithar, Single basin double slope solar still with minimum basin depth and energy storing materials, Appl. Energy 87 (2010) 514523

[29] Z.H. Yousef, K.A. Mousa, Modeling and performance analysis of a regenerative solar desalination unit, Appl. Therm. Eng. 24 (2004) 1061-1072.

[30] C. Gerald and P. Wheatley, Applied Numerical Analysis, Addison Wesley, 1984

[31] Z.M. Omara, A.E. Kabeel, M.M. Younes, Enhancing the stepped solar still performance using internal reflectors, Desalination 314 (2013) 67-72

[32] A.E. Kabeel, Performance of solar still with a concave wick evaporation surface, Energy 34 (2009) 1504-1509

[33] US Research Nanomaterials, Inc, http://www.usnano.com/home

\section{NOMENCLATURE}

A Area, $\mathrm{m}^{2}$

$\mathrm{C}_{\mathrm{p}} \quad$ Heat capacity, $\mathrm{J} / \mathrm{kg}^{\circ} \mathrm{C}$

d Width of the glass cover, $\mathrm{m}$

$\mathrm{Gr}$ Grashof number

$\mathrm{h}_{\mathrm{bnf}}$ Convection heat transfer coefficient between the basin and nanofluids, $\mathrm{W} / \mathrm{m}^{2}{ }^{\circ} \mathrm{C}$.

$\mathrm{h}_{\mathrm{ca}}$ Convection heat transfer coefficient with the ambient, $\mathrm{W} / \mathrm{m}^{2}{ }^{\circ} \mathrm{C}$

$\mathrm{h}_{\mathrm{cnf}}$ Convection heat transfer coefficient between the nanofluids in basin and glass, $\mathrm{W} / \mathrm{m}^{2}{ }^{\circ} \mathrm{C}$

$\mathrm{h}_{\mathrm{fg}} \quad$ Latent heat of vaporization, $\mathrm{J} / \mathrm{kg}$

I Solar insolation normal to glass cover, $\mathrm{W} / \mathrm{m}^{2}$

$\mathrm{k}$ Thermal conductivity, $\mathrm{W} / \mathrm{m}^{\circ} \mathrm{C}$
$\mathrm{L} \quad$ Length of glass cover, $\mathrm{m}$

m Mass, $\mathrm{kg}$

$\mathrm{m}_{\mathrm{re}} \quad$ Rate of mass evaporation, $\mathrm{kg} / \mathrm{s}$

$\mathrm{P} \quad$ Vapour pressure, $\mathrm{Pa}$

Pr Prandtl number

$Q_{\text {bnf }}$ Heat transfer from basin to nanofluids in basin, $\mathrm{W}$

$\mathrm{Q}_{\mathrm{cg}} \quad$ Heat transfer from glass to ambient, $\mathrm{W}$

$\mathrm{Q}_{\mathrm{cnf}}$ Heat transfer from nanofluids in basin to glass, W

$\mathrm{Q}_{\mathrm{e}} \quad$ Heat transfer due to evaporation, W

$\mathrm{Q}_{\text {loss }}$ Heat transfer from basin to ambient, W

$\mathrm{Q}_{\mathrm{mw}} \quad$ Energy needed to heat makeup water to water basin temperature, $\mathrm{W}$

$\mathrm{Q}_{\mathrm{rg}} \quad$ Radiation heat transfer from glass to ambient, W

$\mathrm{Q}_{\mathrm{rnf}}$ Radiation heat transfer from nanofluids in basin to glass, $\mathrm{W}$

$\mathrm{t}$ Temperature, ${ }^{\circ} \mathrm{C}$

$\mathrm{U} \quad$ Heat loss coefficient from basin and sides to ambient, $\mathrm{W} / \mathrm{m}^{2} \mathrm{~K}$

$\mathrm{V}_{\mathrm{a}} \quad$ Wind velocity, $\mathrm{m} / \mathrm{s}$

\section{Greek letters}

$\alpha \quad$ Absorption coefficient

$\varepsilon \quad$ Emissivity

$\mu \quad$ Dynamic viscosity, $\mathrm{kg} / \mathrm{m} \mathrm{s}$

$\tau \quad$ Time, $s$

$\rho \quad$ Density, $\mathrm{kg} / \mathrm{m}^{3}$

$X^{\prime} \quad$ Characteristic, $\mathrm{m}$

$\sigma \quad$ Stefan-Boltzmann constant, $\mathrm{W} / \mathrm{m}^{2} \mathrm{~K}^{4}$

$\eta_{d} \quad$ Solar still daily efficiency

\section{Subscripts}

$\begin{array}{ll}\text { a } & \text { Ambient } \\ \text { g } & \text { Basin } \\ \text { nf } & \text { Glass } \\ \text { np } & \text { Nanofluids } \\ \text { w } & \text { Water }\end{array}$

Table 1

Thermophysical properties of nanoparticales [26].

\begin{tabular}{|c|c|c|c|c|}
\hline $\begin{array}{l}\text { Nano- } \\
\text { particles }\end{array}$ & $\begin{array}{c}C p_{n p} \\
(\mathrm{~J} / \mathrm{kg} . \mathrm{K})\end{array}$ & $\begin{array}{c}K_{n p} \\
(\mathrm{~W} / \mathrm{m} \mathrm{K})\end{array}$ & $\begin{array}{c}\boldsymbol{\rho}_{n p} \\
\left(\mathrm{~kg} / \mathbf{m}^{3}\right)\end{array}$ & $\begin{array}{c}\boldsymbol{\beta}_{n p} \\
(\mathbf{1} / \mathbf{K})\end{array}$ \\
\hline $\mathrm{Al}_{2} \mathrm{O}_{3}$ & 733 & 40 & 3960 & $24 \times 10^{-6}$ \\
\hline $\mathrm{CuO}$ & 551 & 33 & 6000 & $51 \times 10^{-6}$ \\
\hline $\mathrm{TiO}_{2}$ & 692 & 8.4 & 4230 & $24 \times 10^{-6}$ \\
\hline $\mathrm{SiO}_{2}$ & 765 & 36 & 3970 & $63 \times 10^{-7}$ \\
\hline
\end{tabular}

Table 2

Physical and operating parameters used in the theoretical calculation [31].

\begin{tabular}{|lccccc|}
\hline Item & $\begin{array}{c}\text { mass } \\
(\mathrm{kg})\end{array}$ & $\begin{array}{c}\text { Area } \\
\left(\mathrm{m}^{2}\right)\end{array}$ & $\begin{array}{c}\mathrm{C}_{\mathrm{p}} \\
(\mathrm{J} / \mathrm{kg} \mathrm{K})\end{array}$ & $\alpha$ & $\varepsilon$ \\
\hline Saline water & $\mathbf{5 . 9}$ & 1.16 & $\mathbf{4 1 9 0}$ & $\mathbf{0 . 0 5}$ & $\mathbf{0 . 9 6}$ \\
\hline Glass cover & $\mathbf{9 . 0}$ & 1.12 & $\mathbf{8 4 0}$ & $\mathbf{0 . 0 5}$ & $\mathbf{0 . 8 5}$ \\
\hline Besine plate & $\mathbf{1 4 . 5}$ & $\mathbf{1 . 1 6}$ & $\mathbf{4 6 0}$ & $\mathbf{0 . 9 5}$ & $-\cdots$ \\
\hline
\end{tabular}


Theoretical Performance Comparison of Stepped Solar Still Using Different Nanofluids

Y.A.F. El-Samadony, S.A. El-Agouz and A.E. Kabeel

Table 3

Productivity cost evaluation

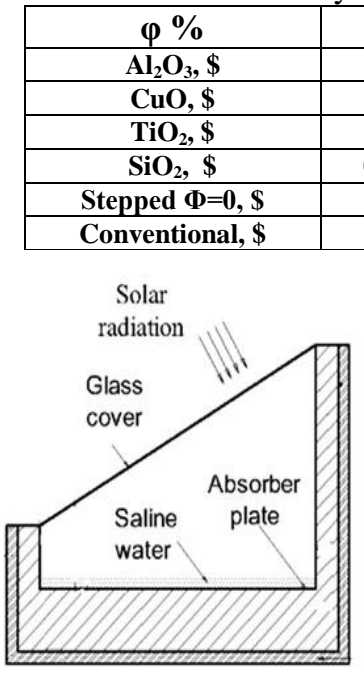

(a)

\begin{tabular}{|c|c|c|}
\hline $\mathbf{0 . 6}$ & $\mathbf{2}$ & $\mathbf{4}$ \\
\hline 0.09 & 0.24 & 0.45 \\
\hline 0.13 & 0.36 & 0.71 \\
\hline 0.08 & 0.23 & 0.43 \\
\hline 0.085 & 0.24 & 0.44 \\
\hline \multicolumn{3}{|c|}{$\mathbf{0 . 0 3 2 9}$} \\
\hline
\end{tabular}

Solar

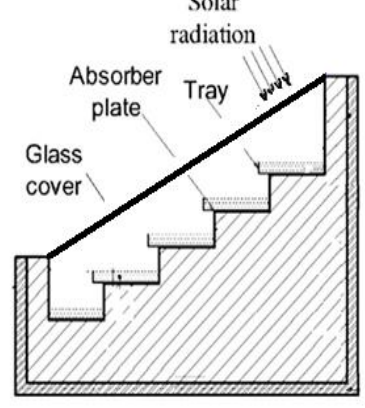

(b)

Figure (1) Solar still, (a) conventional still; (b) Stepped still.

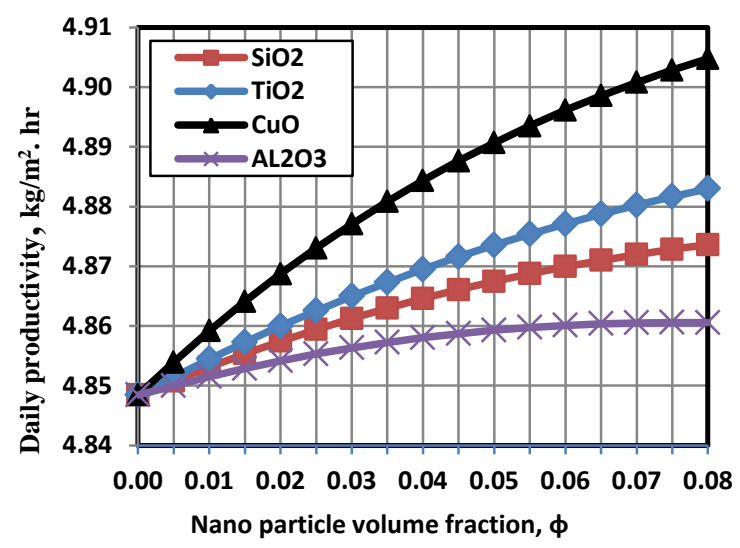

Figure (2) variation of the solar still distillate daily productivity with a nano particle volume fraction of different nano materials

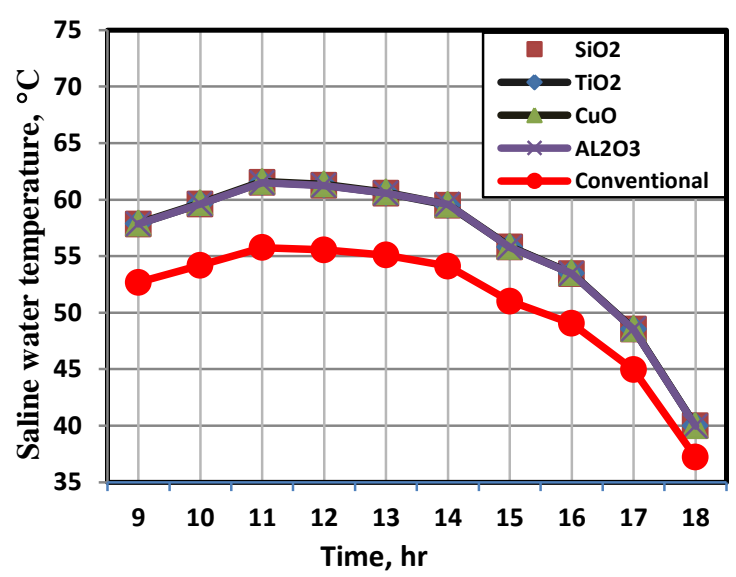

Figure (3) variation of the saline water temperature during the daytime for conventional still and stepped still using nano-particle

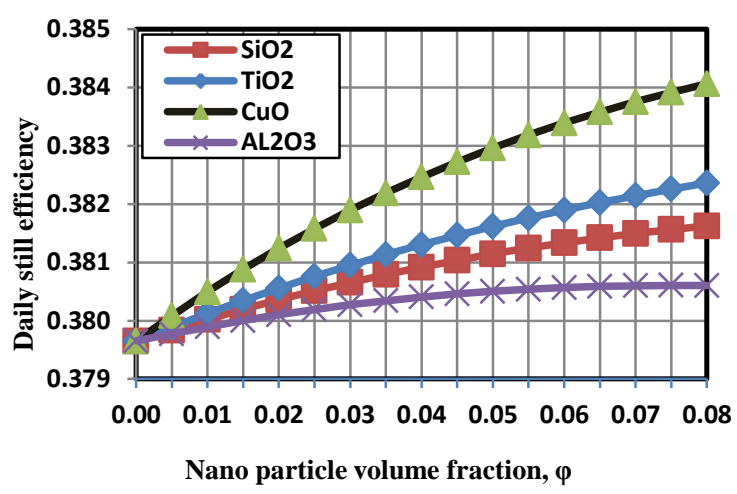

Figure (4) variation of the solar still daily efficiency with nano particle volume fraction of different nano materials

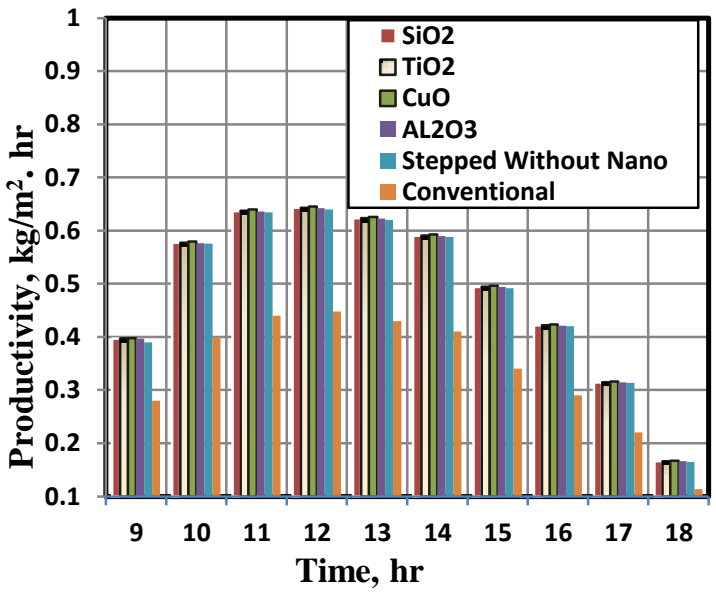

Figure (5) variation of the stepped and conventional solar still distillate hourly productivity with different nano particle materials

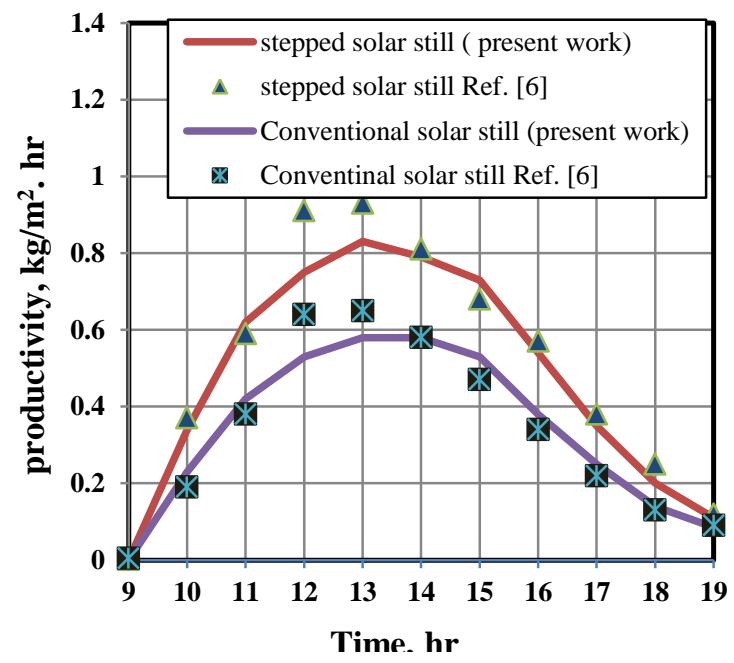

Figure (6) Comparison between the present work and Omara et al [31] output resultants. 